\section{New Estonian records and amendments: Lichenized fungi}

\author{
Ljudmilla Martin
}

Euroacademy, Mustamäe Rd. 4, 10621 Tallinn, Estonia.

E-mail:1martin@euroakadeemia.ee

Three species of lichenized fungi, Caloplaca dischroa, Rhizocarpon submodestum, and Rimularia intercedens, are reported as new for Estonia; one taxon, Diplotomma lutosum, which was previously considered to be extinct from the local lichen biota, was re-discovered. Two further rare species, Collema crispum and Leptogium plicatile, are additionally recorded. The abbreviations are used as follows: (1) for the country region: NW - northwestern part of Estonia, NE - northeastern part, WIs - western islands; (2) for frequency classes (Freq.): rr - very rare (1-2 localities), $r$ - rare (3-5 localities), according to Randlane \& Saag (1999); (3) for the collectors: JM - Jüri Martin, LM - Ljudmilla Martin. The specimens are deposited in the lichen herbarium of the Euroacademy (ICEB).

Caloplaca dichroa Arup - NW: Harju Co., Paldiski, north-eastern part of Pakri Peninsula, the edge of the plateau $\left(59^{\circ} 22^{\prime} 47^{\prime \prime} \mathrm{N} 24^{\circ} 05^{\prime} 11^{\prime \prime} \mathrm{E}\right)$, on limestone pebbles, leg. LM \& JM, 29 Jun 2009, det. LM, 7 Mai 2011 (ICEB 10657); Harju Co., Harku Comm., Vääna-Jõesuu, about $100 \mathrm{~m}$ from the sea coast $\left(59^{\circ} 26^{\prime} \mathrm{O} 2^{\prime \prime} \mathrm{N} 24^{\circ} 21^{\prime} \mathrm{O} 3^{\prime \prime} \mathrm{E}\right)$, ruins of buildings, on concrete, leg. LM \& JM, 27 Apr 2008, det. LM, 11 Jun 2012 (ICEB 10658). Samples are fertile. Freq.: rr. - Recorded in Austria, Denmark, Finland, Germany and Sweden (the islands Gotland and Öland), (Arup, 2006); it is also very common in England (Powell \& Vondrák, 2012), north-western European Russia (Vondrák et al., 2010), Poland (Wilk, 2012), and in the Black Sea region (Vondrák et al., 2009).

Collema CRISPum (Hudson) Weber ex F.H. Wigg. - NW: Harju Co., Harku Comm., Muraste limestone quarry $\left(59^{\circ} 27^{\prime} 21^{\prime \prime} \mathrm{N} 24^{\circ} 28^{\prime} 20^{\prime \prime} \mathrm{E}\right)$, on limestone, leg. LM \& JM, 2 Oct 1999, det. LM, 2 Apr 2008 (ICEB 260). Freq.: r. - This species has previously been reported in Estonia for island Saaremaa (Trass \& Randlane, 1994; Suija et al., 2010), but no local samples were available in Estonian herbaria before now. The taxon is cosmopolitan, and is considered as quite common and widespread on calciferous soils and rocks (Jørgensen, 2007; Smith et al., 2009).

Diplotomma lutosum A. Massal. - NW: Harju Co., Naissaar Island $\left(59^{\circ} 35^{\prime} 52^{\prime \prime N} 24^{\circ} 30^{\prime} 37^{\prime \prime E}\right)$, ruins of fortifications from early $20^{\text {th }} \mathrm{c}$., on concrete, leg. LM \& JM, 15 Oct 2006, det. LM, 26 Jun 2007 (ICEB 10659). Freq.: rr. - This taxon has earlier been recorded in Estonia in the early 20th $\mathrm{c}$. in the surroundings of Tallinn (Nordin, 2000), and was considered to be locally extinct (Randlane et al., 2012).

LePTOGIUM PLiCATILE (Ach.) Leighton - NW: Harju Co., Harku Comm., Muraste limestone quarry $\left(59^{\circ} 27^{\prime} 21^{\prime \prime N} 24^{\circ} 28^{\prime} 20^{\prime \prime} \mathrm{E}\right)$, on limestone, leg. LM \& JM, 2 Oct 1999, det. LM, 3 Apr 2008 (ICEB 10660); Wls: Saaremaa Island, Kaugatoma pank, coastal hill $\left(58^{\circ} 03^{\prime} 27^{\prime \prime N} 22^{\circ} 13^{\prime} 46^{\prime \prime} \mathrm{E}\right)$, on limestone pebbles, leg. LM \& JM, 20 Jul 2000, det. LM, 3 Apr 2008 (ICEB 288, 298). Freq.: r. L. plicatile has earlier been collected at the end of $19^{\text {th }}$ c. by Bruttan in NE, Lääne-Virumaa Co. (Randlane \& Trass, 1994), and in 2004 in NW, Harjumaa Co., Kostivere karst field (Aptroot et al., 2005).

RHIZOCARPON SUBMODESTUM (Vainio) Vainio - NW: Harju Co., the central part of Naissaar Island $\left(59^{\circ} 33^{\prime} 21^{\prime \prime N ~} 24^{\circ} 31^{\prime} 12^{\prime \prime E}\right)$, ruins of fortifications from the end of $20^{\text {th }}$ c., on granite pebble, leg. LM \& JM, 15 Oct 2006, det. LM, 29 Jun 2013 (ICEB 10661). Freq.: rr.

Rimularia InTERCEDEns (H. Magn.) Coppins - NW: Harju Co., Mohni Island, coastal hill (59 40'31"N $\left.25^{\circ} 48^{\prime} 13^{\prime \prime} \mathrm{E}\right)$, on granite pebble in a well-lit place, leg. LM, 27 Sep 2000, det. LM, 14 Oct 2012 (ICEB 9844). Freq.: rr. - Apothecia are very rare, but the taxon is readily identified by the nipplelike papillate areoles (Smith et al., 2009).

\section{ACKNOWLEDGEMENTS}

The author is grateful to Dr. T. Randlane for valuable comments. 


\section{REFERENCES}

Aptroot, A., Czarnota, P., Jüriado, I., Kocourková, J., Kukwa, M., Lõhmus, P., Palice, Z., Randlane, T., Saag, L., Sérusiaux, E., Sipman, H., Sparrius, L., Suija, A. \& Thüs, H. 2005. New or interesting lichens and lichenicolous fungi found during the 5th IAL Symposium in Estonia. Folia Cryptogamica Estonica 41: 13-22.

Arup, U. 2006. A new taxonomy of the Caloplaca citrina group in the Nordic countries, except Iceland. Lichenologist 38(1): 1-20.

Jørgensen, P. M. 2007. Collemataceae. In: Nordic Lichen Flora. Vol. 3. The Nordic Lichen Society, Udevalla, pp. 14-42.

Nordin, A. 2000. Taxonomy and phylogeny of Buellia species with pluriseptate spores (Lecanorales, Ascomycotina). Symbolae Botanicae Upsalenses 33: $1-117$.

Powell M. \& Vondrák J. 2012. Yellow sorediate crusts called "Caloplaca citrina" in England. British Lichen Society Bulletin 110: 20-24.

Randlane, T. \& Saag, A. (eds) 1999. Second checklist of lichenized, lichenicolous and allied fungi of Estonia. Folia Cryptogamica Estonica 35: 1-132.

Randlane, T., Saag, A. \& Suija, A. 2012. Lichenized, lichenicolous and allied fungi of Estonia. Ver. December 28, 2012. - http://esamba.bo.bg.ut.ee/ checklist/est/home.php

Smith, C. W., Aptroot, A., Coppins, B. J., Fletcher, A., Gilbert, O. L., James, P. W. \& Wolseley, P. A. 2009. The Lichens of Great Britain and Ireland. British Lichen Society, London. 1046 pp.

Suija, A., Czarnota, P., Himelbrant, D., Kowalewska, A., Kukwa, M., Kuznetsova, E., Leppik, E., Motiejūnaitè, J., Piterāns, A., Schiefelbein, U., Skazina, M., Sohrabi, M., Stepanchikova, I. \& Veres, K. 2010. The lichen biota of three nature reserves in island Saaremaa, Estonia. Folia Cryptogamica Estonica 47: 85-96.

Trass H. \& Randlane T. 1994. Eesti suursamblikud. Tartu. 399 pp. (In Estonian).

Vondrák, J., Říha, P., Arup, U. \& Søchting, U. 2009. The taxonomy of the Caloplaca citrina group (Teloschistaceae) in the Black Sea region; with contributions to the cryptic species concept in lichenology. Lichenologist 41: 571-604.

Vondrák, J., Redchenko, O., Himelbrant, D., Stepanchikova, I., Kuznetsova, E. 2010. Some sterile Caloplaca crusts identified by molecular data from the Leningrad region (Russia). Folia Cryptogamica Estonica 47: 97-99.

Wilk, K. 2012. Calcicolous species of the genus Caloplaca in the Polish Western Carpathians. Polish Botanical Studies 29: 1-92.

\section{New Estonian records: Lichenicolous fungi}

\author{
Ave Suija \\ Institute of Ecology and Earth Sciences, University of \\ Tartu, Lai St. 38/40, 51005 Tartu, Estonia. E-mail: ave. \\ suija@ut.ee
}

Five species of lichenicolous fungi are reported as new for Estonia. The abbreviations follow Randlane \& Saag (1999), (1) for the country regions: NW - northwestern part of Estonia, NE - northeastern part, SE - southeastern part, SW - southwestern part; (2) for frequency classes (Freq.): rr - very rare (1-2 localities). Cited specimens are kept in the lichenological herbarium of the Natural History Museum, University of Tartu (TU).

ARthonia subfuscicola (Linds.) Triebel - SW: Pärnu Co., Häädemeeste comm., retention cut of eutrophic boreo-nemoral forest $\left(58.06041^{\circ} \mathrm{N}\right.$ $\left.24.67858^{\circ} \mathrm{E}\right)$, on Lecanora carpinea growing on Acer platanoides, leg. P. Lõhmus 6 Oct 2007, det. A. Suija. Freq.: rr.

Epicladonia simplex D. Hawksw. - SE: Põlva Co., Värska Comm., Mustoja Landscape Reserve, Surnumäe sand-pit $\left(57.88185^{\circ} \mathrm{N} 27.6305^{\circ} \mathrm{E}\right)$, on Cladonia sp. on ground, leg. A. Suija \& J. Liira, 2 June 2012, det. A. Suija (TU65714). Freq.: rr.

Nectriopsis Parmeliae (Berk. \& M.A. Curtis) M.S. Cole \& D. Hawksw. - SW: Pärnu Co., Vändra Comm., Kullimaa village $\left(58.56925^{\circ} \mathrm{N}\right.$ $24.93836^{\circ} \mathrm{E}$ ), drained birch forest of Filipendula paludifying forest site type, on squamules of Cladonia ochrochlora growing on base of Betula pendula, leg. J. Liira, Sep 2012, det. A. Suija (TU64979); Pärnu Co., Vändra Comm., Kullimaa village $\left(58.56743^{\circ} \mathrm{N} 24.94237^{\circ} \mathrm{E}\right)$, drained birch forest of Filipendula paludifying forest site type, on squamules of Cladonia sp. growing on Alnus glutinosa, leg. J. Liira, Sep 2012, det. A. Suija (TU64952). Freq.: rr. 
PRONECTRIA OLIGOSPORA Lowen \& Rogerson NW: Lääne Co., Taebla Comm., Ehmja-Turvalepa special conservation area $\left(58.93357^{\circ} \mathrm{N}\right.$ $23.84895^{\circ} \mathrm{E}$ ), eutrophic boreo-nemoral forest, on Parmelia sulcata on decaying stump, leg. \& det. A. Suija, 26 Sep 2012 (TU64973). Freq.: rr.

TRICHONECTRIA RUBEFACIENS (Ellis \& Everh.) Diederich \& Schroers - SE: Tartu Co., Nõo Comm., Vapramägi Hill $\left(58.25275^{\circ} \mathrm{N} 26.46275^{\circ} \mathrm{E}\right)$, forest dominated by Pinus sylvestris and Picea abies, on Parmelia sulcata on a log of Pinus sylvestris, leg. \& det. A. Suija, 15 Oct 2012 (TU64988); NE: Jõgeva Co., Alam-Pedja Nature Reserve, Puurmani Comm., at the Kirna hiking trail $\left(58.54351^{\circ} \mathrm{N} 26.23364^{\circ} \mathrm{E}\right)$, alder forest, on $P$. sulcata on log of Alnus glutinosa, leg. \& det. A. Suija, 4 Oct 2012 (TU64972). Freq.: rr.

\section{ACKNOWLEDGEMENTS}

The author thanks Jaan Liira and Piret Lõhmus for collecting material. The study was financed by the centre of Excellence (FIBIR) and by the target financing project no. SF0180012s09.

\section{REFERENCES}

Randlane, T. \& Saag, A. (eds) 1999. Second checklist of lichenized, lichenicolous and allied fungi of Estonia. Folia Cryptogamica Estonica 35: 1-132. 
126 Folia Cryptog. Estonica 